\title{
Ecosystem production and respiration in response to eutrophication in shallow temperate estuaries
}

\author{
Charlene D'Avanzo $^{1, *}$, James N. Kremer ${ }^{2}$, Sam C. Wainright ${ }^{3}$ \\ ${ }^{1}$ School of Natural Sciences, Hampshire College, Amherst, Massachusetts 01002, USA \\ ${ }^{2}$ Department of Marine Sciences, University of Connecticut at Avery Point, Groton, Connecticut 06340, USA \\ ${ }^{3}$ Institute of Marine and Coastal Sciences, Rutgers University, New Brunswick, New Jersey 08903-0231, USA
}

\begin{abstract}
Ecosystem metabolism was measured from diel changes in free-water dissolved oxygen in 3 shallow subestuaries of Waquoit Bay on Cape Cod, Massachusetts, USA. Our goal was to relate metabolism to the different levels of nitrogen loading to the subestuaries. Automatic meters recorded $\mathrm{O}_{2}$, temperature, and conductivity continuously at 2 depths in each estuary for 5 to $25 \mathrm{~d}, 7$ to 10 times throughout a year. Day-to-day rates of daytime ecosystem production and nighttime respiration were quite variable, up to $\pm 10 \mathrm{~g} \mathrm{O}_{2} \mathrm{~m}^{-2} \mathrm{~d}^{-1}$ for consecutive days. Daytime ecosystem production was correlated with daily irradiance. At equivalent values of daily insolation, higher production rates were measured in the more heavily N-loaded estuary. Enrichment also resulted in higher rates of respiration. Daily rates of respiration and production were uncorrelated during most deployments, yet a strong correlation emerged over the year because both rates changed with season. Annual ecosystem net and gross production (ENP and EGP) increased with $N$ loading in the 3 estuaries. Significant ENP (about $180 \mathrm{~g} \mathrm{O}_{2} \mathrm{~m}^{-2} \mathrm{yr}^{-1}$ ) occurred in the highly enriched system; in the 2 other estuaries receiving lower enrichment rates system respiration ( $R$ ) and production (P) both increased and thus ENP was small $(\mathrm{P} \sim \mathrm{R})$. On an annual basis, metabolism in these estuaries is in balance or slightly autotrophic.
\end{abstract}

KEY WORDS: Ecosystem metabolism - Eutrophication · Estuary

\section{INTRODUCTION}

Nutrient enrichment from anthropogenic sources is a pervasive agent for change in coastal waters (Valiela et al. 1992). Human activity on watersheds increases delivery of nutrients to estuaries via deforestation, agricultural activities, domestic use of fertilizers, and sewage treatment. Nutrient loading to coastal receiving waters worldwide has led to excessive growth of algae, anoxia and hypoxia, and loss of shellfish and finfish habitat (McComb et al. 1981, Officer et al. 1984, Price et al. 1985, D'Avanzo \& Kremer 1994). While ecosystem processes (e.g. nutrient and trophic dynamics) in coastal waters receiving significant nutrient inputs are certain to be affected, fundamental knowledge is lacking about the specific responses of these systems to enrichment (Nixon et al. 1986, Smith et al. 1991, Nixon 1992). Oviatt et al. (1986) have shown how system

·E-mail: cdavanzo@hampshire.edu production $(\mathrm{P})$ and respiration $(\mathrm{R})$ change along a nutrient loading gradient in estuarine mesocosms, but this fundamental response of ecosystem metabolism to different levels of nutrient enrichment has not been studied in natural estuaries. There is even debate on whether coastal systems are nominally heterotrophic or autotrophic on a net annual basis (Smith et al. 1991)

The Waquoit Bay Land-Margin Ecosystem Research project (WBLMER; Valiela et al. 1992) is a regional scale 'natural experiment' in nutrient loading of an embayment on Cape Cod, Massachusetts, USA. The study is designed to assess how the degree of urbanization in coastal watersheds affects delivery of nutrients to 3 estuaries entering Waquoit Bay, and how this differential nutrient loading subsequently alters ecological processes in the estuaries. In the populated watersheds serving Waquoit Bay, domestic wastewater from septic tanks appears to be the primary source of anthropogenic nutrients enriching the bay (Valiela et al. 1992, in press). 
The measurement of ecosystem production and respiration is central to the WBLMER. To determine the response of the impacted estuaries as whole units, we measure total system metabolism, one of the few readily measurable integrative properties of ecological systems. Although whole system metabolism could be calculated from measurements of components of the systems (e.g. phytoplankton plus benthos), metabolism measurements made in experimental enclosures may include artifacts and summing such measurements has led to underestimates of system photosynthesis and respiration in estuaries (Kemp \& Boynton 1980).

Obtaining measurements of ecosystem metabolism in estuaries is challenging because estuaries are hydrologically complicated and traditional approaches with hand-held instruments are very time consuming. Studies of system production and respiration in estuaries are few and most are limited to very few days of sampling seasonally (i.e. Nixon \& Oviatt 1973, Kemp \& Boynton 1980, Carmouze et al. 1991, Reyes \& Merino 1991). We felt that automated diel measurements of metabolism from lengthy deployments would allow us to estimate annual metabolism in Waquoit Bay more accurately and to quantify differences in metabolic rates between estuaries in response to nutrient enrichment.

To determine the effects of nutrient loading on the ecosystem, we compared estuaries in Waquoit Bay which receive different levels of nutrient loading and which experience different physical residence times as to: (1) annual cycle of daily ecosystem production and respiration, (2) response of ecosystem metabolism to light and temperature, (3) annual patterns of ecosystem net autotrophy or heterotrophy, and (4) annual ecosystem gross and net production. We were particularly interested in quantifying if ecosystem production and respiration are enhanced with nutrient addition and whether the enriched estuaries in Waquoit Bay are net autotrophic and are likely to export organic matter to surrounding waters.

\section{METHODS}

Site description. Waquoit Bay is a relatively small (630 ha), shallow (mean depth $1.1 \mathrm{~m}$, maximum depth $3 \mathrm{~m}$ ), and microtidal (mean tidal range $60 \mathrm{~cm}$ ) coastal embayment on southwestern Cape Cod. Freshwater enters the bay via groundwater seepage and groundwater-fed streams. As a result, these tributaries and much of the bay are persistently salinity stratified (D'Avanzo \& Kremer 1994). Freshwater turnover times are about 0.5 to $2 \mathrm{~d}$ in the tributary estuaries that we studied (R. Geyer, Woods Hole Oceanographic Institute, pers. comm.). Three watersheds are the focus of the WBLMER; they differ in housing density and area and consequently in nutrient contamination of groundwater from septic leachfields, lawn fertilizers, and precipitation (Valiela et al. 1992, in press). These differences are reflected in field measurements of $N$ in freshwater entering the 3 estuaries (Table 1 ).

The most obvious response to $N$ enrichment in the Childs and Quashnet River estuaries is growth of benthic macroalgae. Seaweed, primarily Gracilaria tikvahiae and Cladophora vagabunda, are dominant producers in both of these estuaries; biomass of macroalgae is very high in Childs River but lower in Quashnet River (Table 1). Dramatic diel excursions of $\mathrm{O}_{2}$ concentrations occur in the bottom water of these estuaries largely as a result of macroalgal metabolism (D'Avanzo \& Kremer 1994). In Sage Lot Pond, where anthropogenic input of nutrients is comparatively low, eelgrass Zostera marina is dominant and abundant (Table 1) as was historically the case in the Childs River and Quashnet River estuaries (Costa 1988).

Ecosystem metabolism measurements. We measured ecosystem production and respiration in the 3 estuaries of Waquoit Bay by monitoring free-water $\mathrm{O}_{2}$ with automated instruments during 1 to 3 wk deployments throughout a year. Thus metabolism in the 3 estuaries could be compared on the same days as well as averaged over a range of tidal cycles and weather conditions. Two automated meters were deployed at

Table 1 Attributes of the 3 estuaries in Waquoit Bay, Cape Cod, Massachusetts, USA

\begin{tabular}{|c|c|c|c|c|c|c|}
\hline \multirow[t]{2}{*}{ Estuary } & \multirow{2}{*}{$\begin{array}{l}\text { Area } \\
\text { (ha) }\end{array}$} & \multirow{2}{*}{$\begin{array}{l}\text { Mean depth } \\
\text { (m) }\end{array}$} & \multirow{2}{*}{$\begin{array}{l}\text { Residence } \\
\text { time }(d)^{d}\end{array}$} & \multicolumn{2}{|c|}{ Macrophyte } & \multirow{2}{*}{$\begin{array}{l}\text { Freshwater } \\
\qquad\left[\mathrm{NO}_{3}\right]^{\mathrm{C}}\end{array}$} \\
\hline & & & & Dominant species & Biomass $\left(\mathrm{g} \mathrm{m}^{-2}\right)^{b}$ & \\
\hline Childs River & 13.2 & 1.1 & 2 & Cladophora vagabunda & 402 & $30-40$ \\
\hline Quashnet River & 16.8 & 0.5 & 0.5 & Cladophora vagabunda & 164 & $8-10$ \\
\hline Sage Lot Pond & 16.9 & 0.9 & 2 & Zostera marina & 101 & none \\
\hline
\end{tabular}


1 location midway along the length in each estuary. One meter floated near the surface and the second was $0.25 \mathrm{~m}$ off the bottom

Ecosystem metabolism was calculated from hourly averages of $\mathrm{O}_{2}$, temperature, and salinity measurements recorded every $15 \mathrm{~min}$ at 2 depths with ENDECO model 1184C meters. Deployments were for 5 to 25 d periods from July 1991 through July 1992. There were 10 deployments of the meters over the year in Childs River, 9 in Sage Lot Pond, and 7 in Quashnet River due to midwinter equipment failure. The meters were shown to be insensitive to fouling but subject to irregular changes in calibration coefficients (Wainright et al. 1995). Calibration of the ENDECO 1184 pulsed $\mathrm{O}_{2}$ sensors is a serious consideration (Wainright et al. in press), so all instruments were fully calibrated at 2 temperatures and $2 \mathrm{O}_{2}$ levels before and after each deployment. In addition, meters were checked by comparison with $\mathrm{O}_{2}$ readings made in the field during the deployments as well as by titrations from a seawater bath back at the laboratory before and after deployments. A single set of coefficients was selected which was used to obtain hourly rates of change throughout the whole deployment. Hourly rates of change determined from these corrected $\mathrm{O}_{2}$ concentrations were adjusted for diffusion (see below) and summed over an areal basis for an average depth. Daytime ecosystem production was calculated as the sum of positive hourly rates of change over each day and nighttime ecosystem respiration from summed negative hourly rates of change at night (Table 2).

Irradiance was logged with a LICOR LI-1000 quantum sensor nearby at the Waquoit Bay Estuarine Research Reserve at the head of Waquoit Bay. During the deployments Onset Tattletale 2-B computers coupled to Digitar \#7902 anemometers recorded wind velocity each minute at each location. Relationships defining the gas exchange coefficient versus wind velocity determined for each estuary were not different and a single empirical expression was used. The net flux due to gas exchange across the air-sea interface was calculated each hour from averaged wind speed and $\mathrm{O}_{2}$ concentration in the surface water, relative to saturation determined from logged temperature and salinities (C. D'Avanzo, J. N. Kremer \& S. C. Wainwright unpubl.)

$$
\begin{gathered}
S D=0.209\left(O_{\text {sat }}-O_{o b s}\right) / O_{\text {sdt }} \\
K=0.56 \mathrm{e}^{10.15 w_{10 !}} \\
D=K \cdot S D
\end{gathered}
$$

where $S D$ (atm) is the saturation deficit, $O_{\text {obs }}$ and $O_{\text {sat }}$ are the $\mathrm{O}_{2}$ concentrations (ppm) observed and calculated at atmospheric equilibrium, $K\left(\mathrm{~g} \mathrm{O}_{2} \mathrm{~m}^{-2} \mathrm{~h}^{-1} \mathrm{~atm}\right)$ is the gas exchange coefficient (see Table 2), $W_{10}$ is the wind speed $\left(\mathrm{m} \mathrm{s}^{-1}\right)$ measured on site and con- verted to a standard height of $10 \mathrm{~m}$ with a logarithmic correction (Hartman \& Hammond 1985, D'Avanzo et al. unpubl.), and $D\left(\mathrm{~g} \mathrm{O}_{2} \mathrm{~m}^{-2} \mathrm{~h}^{-1}\right)$ is diffusion flux

In Table 2 we show how hourly measurements of 3 variables at 2 depths were used to compute hourly rates of $\mathrm{O}_{2}$ change corrected for atmospheric exchange. Corrected hourly rates were integrated to yield daytime net production and nighttime respiration. In this typical example the diffusion adjustment increased $\mathrm{P}$ because $\mathrm{O}_{2}$ lost during the afternoon exceeded that diffusing into the water column in the morning. In contrast, gas loss and gain during the $13 \mathrm{~h}$ respiratory period was more nearly in balance.

At the start of most deployments, we documented spatial variability of metabolism within the estuaries with dawn and dusk profiles of $\mathrm{O}_{2}$, salinity, and temperature measured at 3 sites along the axis of each estuary for 1.5 to $4 \mathrm{~d}$. Profile data were taken every $0.1 \mathrm{~m}$ through the water column with a YSI stirring model $58 \mathrm{O}_{2}$ and a model $33 \mathrm{~S}-\mathrm{C}$-T meter.

In this study the conventional assumption that diel $\mathrm{O}_{2}$ measurements are being made on the same water mass is suspect. We used the profile data in a detailed analysis evaluating the uncertainty in our rate estimates arising from spatial heterogeneity due to both vertical structure and horizontal variation throughout the estuary (D'Avanzo et al. unpubl.). We quantified variability of computed metabolism arising from morning and late afternoon profiles taken at 3 stations in the Childs River over $4 \mathrm{~d}$ in summer. The stations were located midriver at the head, foot, and middle of the estuary bracketing the location of the 2 continuous recorders. We compared all combinations of one of the 3 morning profiles paired with one of the 3 afternoon profiles (for $\mathrm{P}$, reverse for $\mathrm{R}$ ). If profiles at the 3 stations are considered to be replicates of the conditions in the estuary, we can assess the variability of metabolic rates computed from the profiles with respect to the rate based on the recorders, i.e. whether metabolism measured at the midestuary location represented the reach as a whole for each day or night interval over $4 \mathrm{~d}$.

Residence time and estimates of nutrient loading. We define residence time ( $\left.T_{\text {res }}\right)$ as the average time a parcel of freshwater remains in the estuary. Residence time was calculated by

$$
T_{\text {ress }}=V_{\text {iresh }} / Q_{\mathrm{r}}
$$

where $V_{\text {fresh }}$ is the total volume of freshwater in the estuary and $Q_{\mathrm{r}}$ is river inflow (determined from river water level measurements) (from repeated, intensive CTD surveys; R. Geyer pers. obs.).

$\mathrm{N}$ loading was calculated as the product of groundwater discharge and the $N$ concentration of the groundwater. Discharge was estimated from local annual precipitation times watershed area, less $55 \%$ 


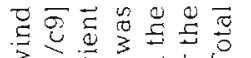

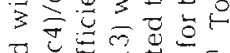

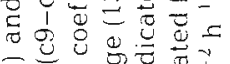

III

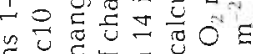

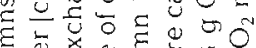

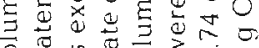

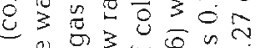

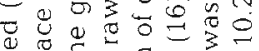

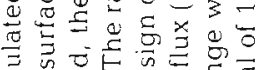

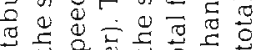

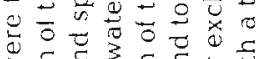

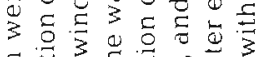

ह

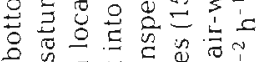

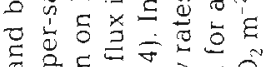

ब

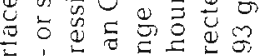

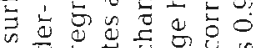

$\Xi \Xi \frac{0}{0}$

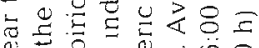

品

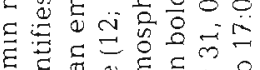

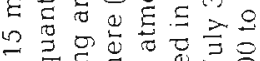

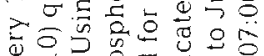

ये

उ

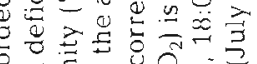

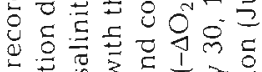

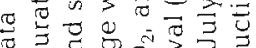

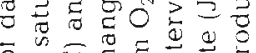

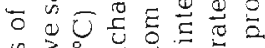

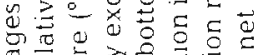

Q

我过

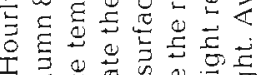

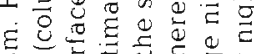

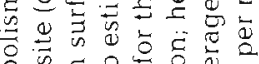

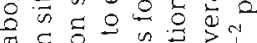

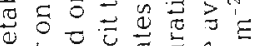

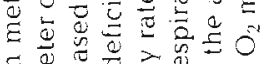

घ

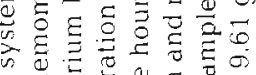

क

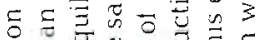

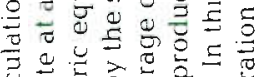

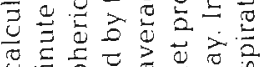

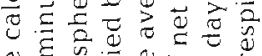

을

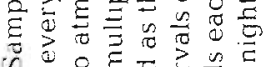

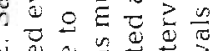

๙

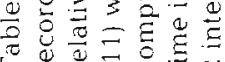

\begin{tabular}{|c|c|c|}
\hline 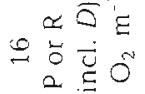 & $\begin{array}{l}\overrightarrow{0} \\
\dot{9} \\
i\end{array}$ & $\stackrel{\overbrace{}}{\varrho}$ \\
\hline 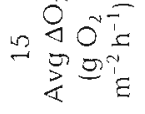 & $\underset{i}{\stackrel{T}{0}}$ & $\begin{array}{l}3 \\
0 \\
0\end{array}$ \\
\hline 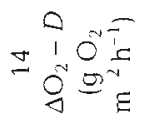 & 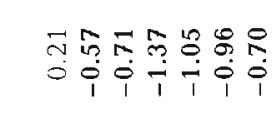 & 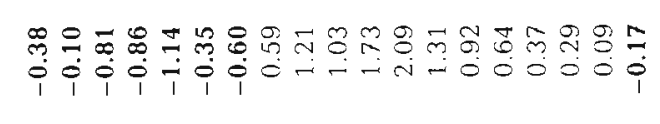 \\
\hline 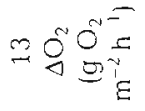 & 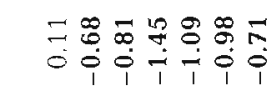 & 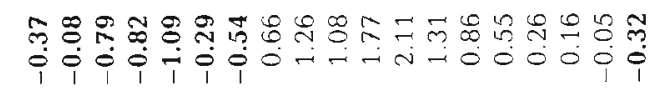 \\
\hline$\because 00^{2=}$ & 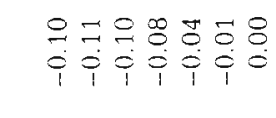 & 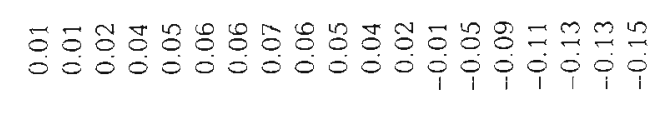 \\
\hline 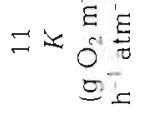 & 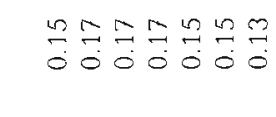 & 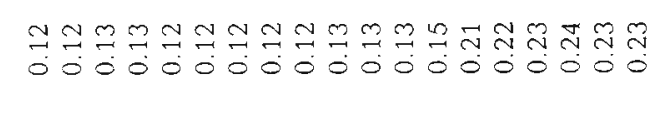 \\
\hline 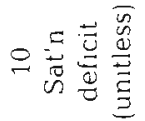 & $\begin{array}{lllllll}3 & 0 & 0 & \pi & 0 & -1 \\
0 & 0 & 0 & 0 & 0 & 0 \\
0 & 0 & 0 \\
0 & 0 & 0 & 0 & 0 & 0 & 0 \\
1 & 1 & 1 & 1 & 1 & 1\end{array}$ & 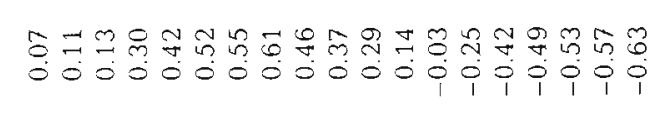 \\
\hline 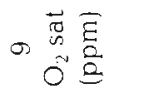 & 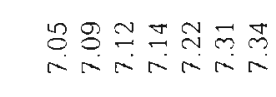 & 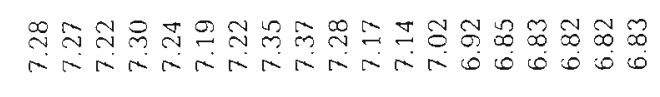 \\
\hline 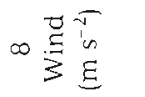 & 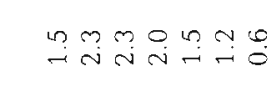 & 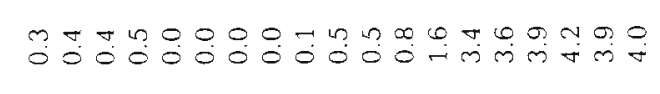 \\
\hline$\sim \sigma \frac{\bar{E}}{\underline{\underline{a}}}$ & 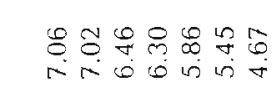 & 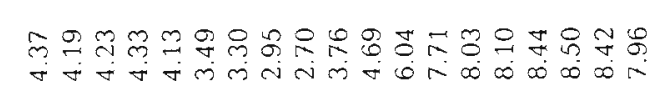 \\
\hline 畄高言 & 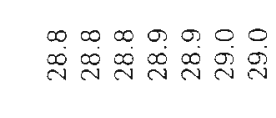 & 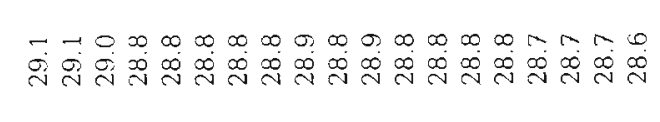 \\
\hline$\omega$ हैछ & 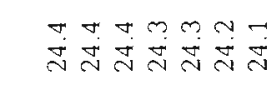 & 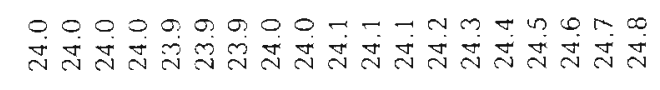 \\
\hline 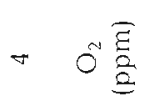 & 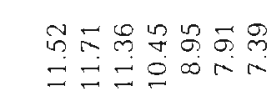 & 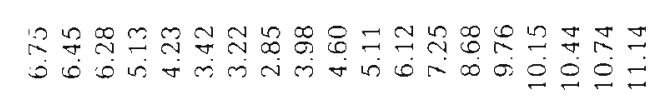 \\
\hline 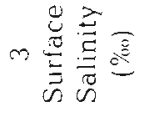 & 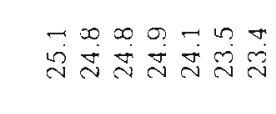 & 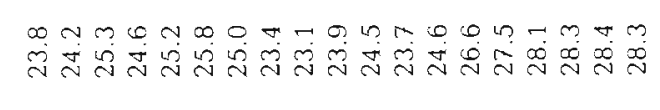 \\
\hline$\sim \stackrel{\stackrel{\vec{\Xi}}{\emptyset}}{\bullet}$ & 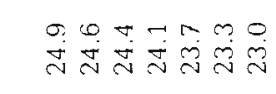 & 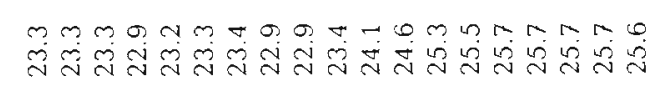 \\
\hline 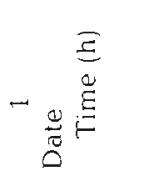 & 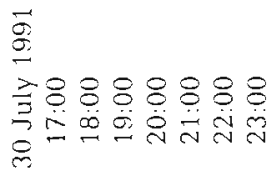 & 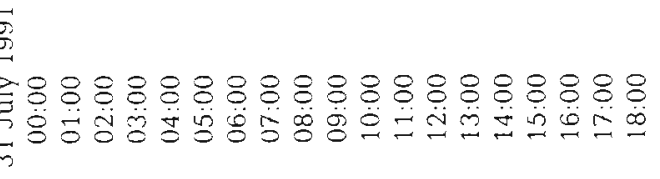 \\
\hline
\end{tabular}


lost to evapotranspiration (Valiela et al. in press). Groundwater $N$ concentration was the arithmetic mean of samples collected at 50 to $100 \mathrm{~m}$ intervals along the periphery of each of the estuaries $(\mathrm{N}=25,10$, 12 for Childs, Quashnet, and Sage Lot respectively; I. Valiela, Marine Biological Laboratory, Woods Hole, pers. comm.). Essentially all of the dissolved inorganic $\mathrm{N}$ in the groundwater entering the Waquoit Bay estuaries is nitrate (Valiela et al. in press).

Terminology. In this paper 'daytime ecosystem production' refers to net primary production in excess of total community respiration during daylight hours, i.e. the sum of apparent daytime increases in $\mathrm{O}_{2}$ corrected for air-sea gas exchange. These rates are reported in $\mathrm{g} \mathrm{O}_{2} \mathrm{~m}^{-2} \mathrm{~d}^{-1}$, either as daily values or as averages over the deployments of 5 to $25 \mathrm{~d}$. 'Nighttime ecosystem respiration' refers to the sum of $\mathrm{O}_{2}$ decreases over the remainder of the $24 \mathrm{~h}$ day corrected for gas exchange, reported in $\mathrm{g} \mathrm{O}_{2} \mathrm{~m}^{-2} \mathrm{~d}^{-1}$ as daily values or as averages over deployments. Our continuous records of $\mathrm{O}_{2}$ indicated that the change from apparent increases (day) to decreases (night) did not correspond well with meteorological dawn and dusk. Thus we calculated our metabolic rates by dividing the day based on the observed changes from positive to negative net rates. 'Ecosystem net production' refers to the $24 \mathrm{~h}$ sum of the previous 2 rates, i.e. $\mathrm{g} \mathrm{O}_{2} \mathrm{~m}^{-2} \mathrm{~d}^{-1}$ produced during the day and not consumed during the diel period. Ecosystem net production is reported here as average daily values over deployments, or as annual totals estimated from integrating average daily values throughout one year. We estimated 'ecosystem gross production' by adding the daytime ecosystem production plus a daytime respiratory demand, assumed to be the hourly average nighttime ecosystem respiration rate times the hours of daylight.

\section{RESULTS}

\section{Daily production and respiration}

Rates of both daytime ecosystem production and nighttime respiration changed considerably from day to day in the Waquoit Bay estuaries. For example, in the 10 deployments of the pulsed $\mathrm{O}_{2}$ sensors in the Childs River, daily metabolic rates ranged from about \pm 1 to nearly $\pm 14 \mathrm{~g} \mathrm{O}_{2} \mathrm{~m}^{-2} \mathrm{~d}^{-1}$ and were highest in midsummer (Fig. 1). These large daily variations in production and respiration illustrate the importance of measuring metabolism over many days. It is clear that extrapolations of metabolism from single or even several days of sampling cannot adequately capture temporal variability in biologically dynamic estuaries.

\section{Spatial heterogeneity}

The variability of the repeated profile measurements throughout the estuary at the start of the deployments allowed us to assess the relative importance of physical factors other than metabolism (such as advection and tidal stage) which might significantly influence diel $\mathrm{O}_{2}$ changes measured in Waquoit Bay. Day-to-day variation was large compared to spatial variation in calculated rates of change within the estuary on one day; the average standard deviation for production and respiration in summer from profiles taken at the start of each deployment was $0.87 \mathrm{~g} \mathrm{O}_{2} \mathrm{~m}^{-2} \mathrm{~d}^{-1}$ ( $\mathrm{N}=21$; see box in Fig. 1). In one detailed study over $4 d$, the rate of production and respiration at the midestuary station was often within \pm 1 and always within $\pm 2 \mathrm{SD}$ of the mean of the rates calculated from combinations of profiles throughout the estuary (see also D'Avanzo \& Kremer unpubl.). Thus, metabolism determined from measurements taken by the continuous recorders located midriver represents $\mathrm{O}_{2}$ changes in the whole reach with better than $95 \%$ confidence.

\section{Daily rates in relation to other factors}

Daytime ecosystem net production varied from day to day in relation to daily changes in insolation during warmer months in the Waquoit Bay estuaries. Daytime production during midsummer in the Childs River was directly proportional to daily light intensity ( $p<$ 0.01; Fig. 2a, solid circles) up to intensities of about $25 \mathrm{E} \mathrm{m}^{-2} \mathrm{~d}^{-1}$. Higher light intensities did not enhance daily production, suggesting that daytime ecosystem production in the Childs River is limited by factors

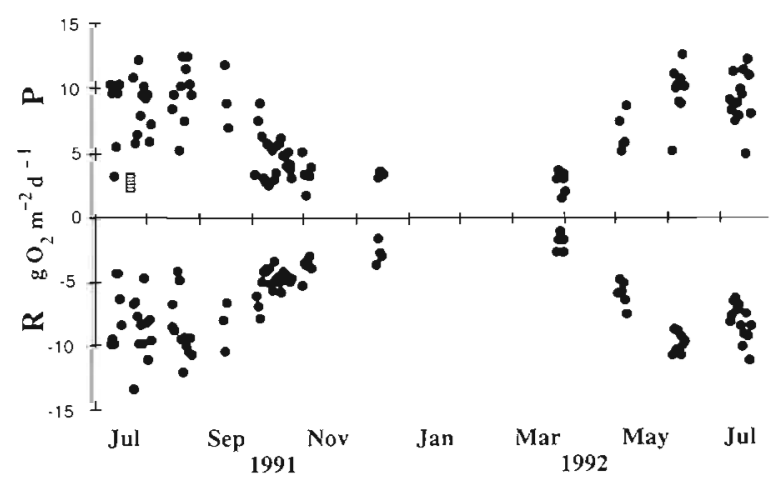

Fig. 1. Day-to-day variation in daily ecosystem production (P) and respiration $\left(\mathrm{R}_{;} \mathrm{O}_{2}\right)$ over a year in 10 deployments of the automated conductivity-temperature- $\mathrm{O}_{2}$ sensors in the Childs River, Waquoit Bay estuary, Cape Cod, MA, USA. (目) Average SD of 3 measurements along the estuary on $4 \mathrm{~d}$ or night cycles in midsummer, an indication of the variability within an estuary 


\section{a}

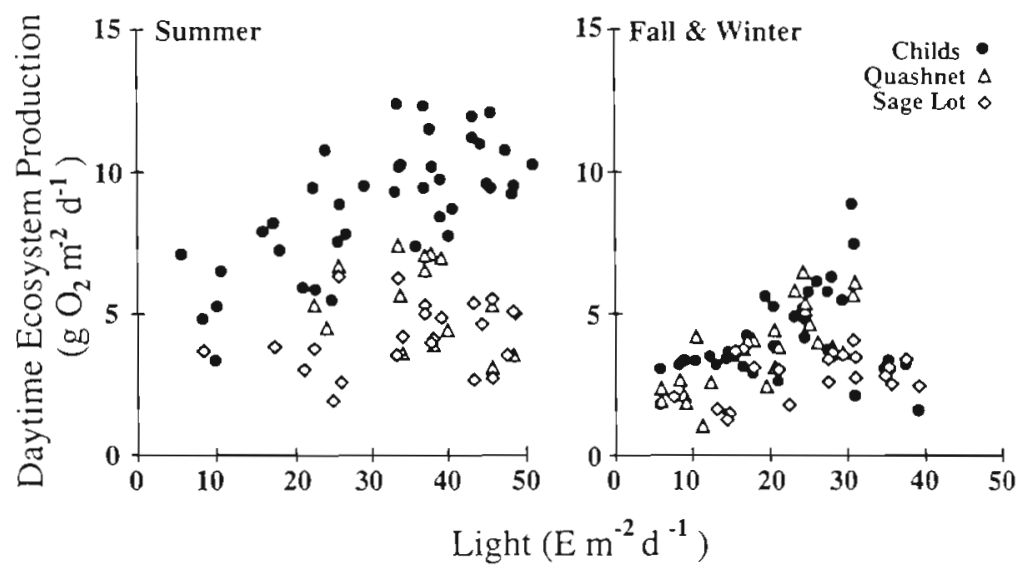

Fig. 2. Daytime ecosystem production as a function of irradiance in the 3 estuaries of Waquoit Bay

other than light during the brightest days in midsummer Summertime daily production in the Sage Lot Pond and Quashnet estuaries was not significantly related to light intensity (Fig. 2a, open symbols), possibly because nutrient limitation or some other factor does not allow expression of light limitation.

Rates of ecosystem net production also appear to be related to nutrient enrichment since production rates at equivalent light intensities were higher in the Childs River compared to the other 2 estuaries (Fig. 2a). There is little overlap between the Childs River points and the Sage and Quashnet data, indicating a strong estuary effect on the relationship between daily light and ecosystem production. It seems that nutrients limit daily production rates to a greater degree in Sage Lot and Quashnet compared to Childs River where high inputs of $\mathrm{N}$ apparently raise daily production to considerably higher rates. The combined effect of $\mathrm{N}$ enrichment and light has been demonstrated experimentally for coastal producers (e.g. Van Raalte et al. 1976) but has not been previously observed for total system procluction

During fall and winter, cold temperatures clearly resulted in lower rates of daytime production (Fig 2b). For example, during bright days in winter, production rates in the Childs River were half to a third of summertime rates on days with similar irradiance. During these cold months, daytime production in the estuaries was not correlated with light intensits. Production rates in fall and winter in the Childs River were generally higher than those in Sage Lot although the distinction between these locations is less clear-cut at this time of year

Daily respiration rates were directly related to daily rates of production over the year (Fig. 3). However, for each deployment we were unable to discern any va- riables that were correlated with the large day-to-day differences in respiration seen in Fig. 1 Nightly respiration rates within a deployment were not related to: production or light on the previous day, minimum or average nighttime $\mathrm{O}_{2}$ concentration, wind and water column stratification during the night, or water temperature during the deployment. $\mathrm{O}_{2}$ is consumed when sulfides deposited as a result of sulfate oxidation are reoxidized at the sediment surface (Jørgensen 1977). Time lags in oxidation of reduced sulfur compounds are an additional variable not accounted for in our analysis, but it is unclear why day-to-day variations would be large. Thus we interpret the correlation in Fig. 3 as a response of both production and respiration to season rather than to any close day-to-day coupling of $\mathrm{P}$ and $\mathrm{R}$. The less-frequent sampling commonly employed might suggest an annual pattern but our measurements suggest that this should not necessarily be interpreted as a close metabolic coupling between $\mathrm{P}$ and $\mathrm{R}$.

\section{Estuary effect}

A more rigorous comparison of metabolism in the estuaries can be made by comparing metabolic rates in Childs River with rate measurements on the same days in Sage Lot or Quashnet River. During summer, daytime ecosystem production rates in the Childs River were higher than those in Sage Lot and Quashnet (below the 1:1 line) on all days (Fig. 4, solid circles)

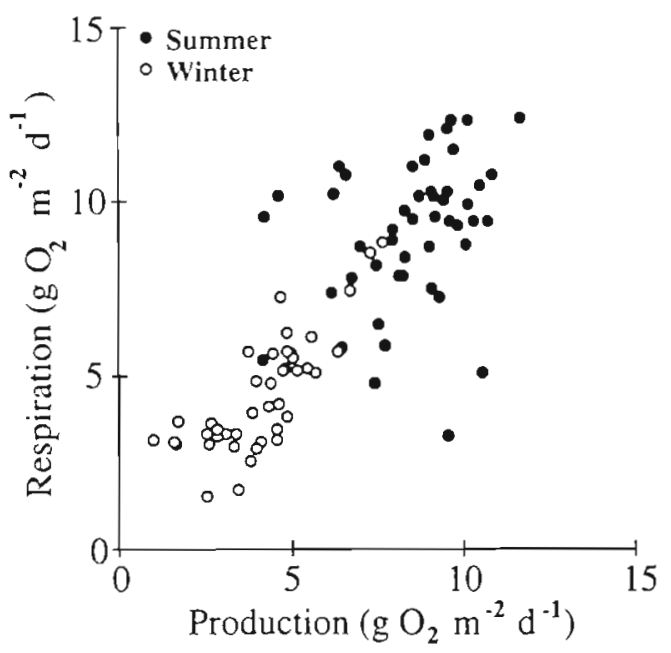

Fig. 3. Relationship between daytime ecosystem production and nighttime respiration in the Childs River over the year 
During fall and winter (Fig. 4, open circles), production rates were also generally higher in Childs River than in Sage Lot Pond and Quashnet River, although the contrast between the estuary pairs was not as great during these cold months. Production for all seasons together was significantly higher in Childs River than in the other 2 estuaries ( $p<0.01$, Wilcoxon matched-pairs signed rank test) Thus the highest ecosystem production corresponds to the estuary receiving the greatest anthropogenic nitrogen input.

Ecosystem respiration during summer was also frequently higher in the Childs River than in Sage Lot Pond and Quashnet River (Fig. 5; $\mathrm{p}=0.05$ for the Sage Lot comparison for all seasons; $p<0.01$ for summer in the Quashnet comparison, other seasons not significant). Apparently, higher rates of production in the Childs River fueled elevated rates of ecosystem respiration in this nutrient loaded system during warmer months. Our findings agree with those of Nixon (1992) and Oviatt et al. (1986) who found that system respiration increased with nutrient loading in the MERL mesocosm eutrophication experiment. In fall and win-

\section{Daytime Ecosystem Production $\left(\mathrm{g} \mathrm{O}_{2} \mathrm{~m}^{-2} \mathrm{~d}^{-1}\right)$}

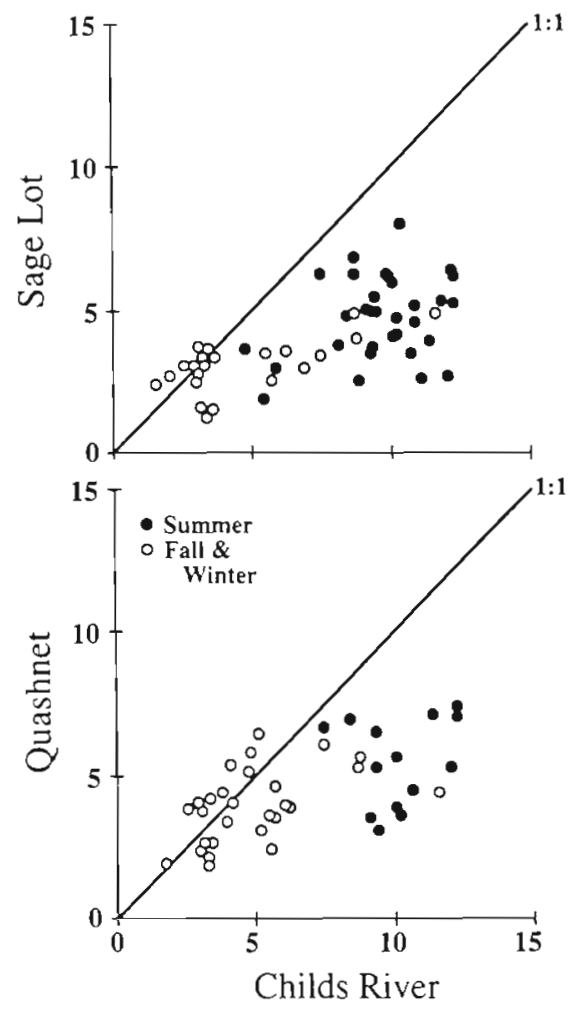

Fig. 4. Comparison of simultaneous measurements of daytime ecosystem production in Childs River versus Sage Lot Pond and Quashnet River, Waquout Bay estuaries. Line indicates a 1:1 comparison

\section{Nighttime Ecosystem Respiration $\left(\mathrm{g} \mathrm{O}_{2} \mathrm{~m}^{-2} \mathrm{~d}^{-1}\right)$}

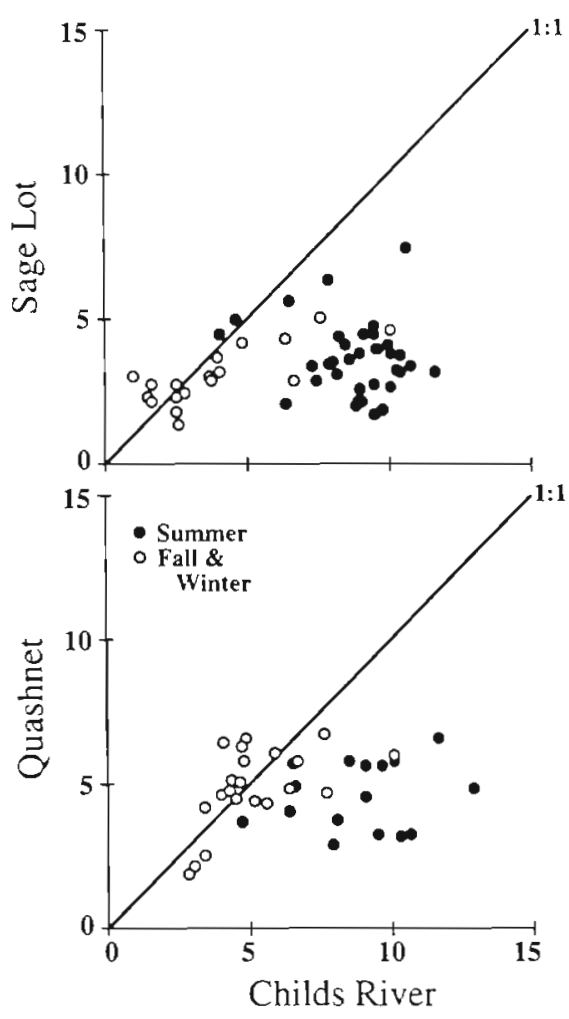

Fig. 5. Comparison of simultaneous measurements of nighttime ecosystem respiration in Childs River versus Sage Lot Pond and Quashnet Ruver. Line indicates a 1:1 comparison

ter, ecosystem respiration rates were similar in the 3 Waquoit Bay estuaries (Fig 5, open circles). It is unclear whether this is because low temperatures caused the rates to converge, masking slight differences, or because temperatures actually negated any nutrient effect on respiration.

\section{Annual production and respiration patterns \\ Seasonal differences}

Daytime production and nighttime respiration in the Childs River ecosystem showed strong seasonality (Fig. 6a). Daytime production (Fig. 6a, open circles) reached $10 \mathrm{~g} \mathrm{O}_{2} \mathrm{~m}^{-2} \mathrm{~d}^{-1}$ in summer, dropping to $3 \mathrm{~g} \mathrm{O}_{2}$ $\mathrm{m}^{-2} \mathrm{~d}^{-1}$ in winter in the Childs River In Quashnet and Sage Lot, average rates were about half those in the Childs River (Fig. 6b, c). Seasonality was apparent but less dramatic, with winter rates dropping to about $2 \mathrm{~g}$ $\mathrm{O}_{2} \mathrm{~m}^{-2} \mathrm{~d}^{-1}$ in Sage Lot; winter data for Quashnet were unavailable, but rates of 2 or $3 \mathrm{~g} \mathrm{O}_{2} \mathrm{~m}^{-2} \mathrm{~d}^{-1}$ are likely. 


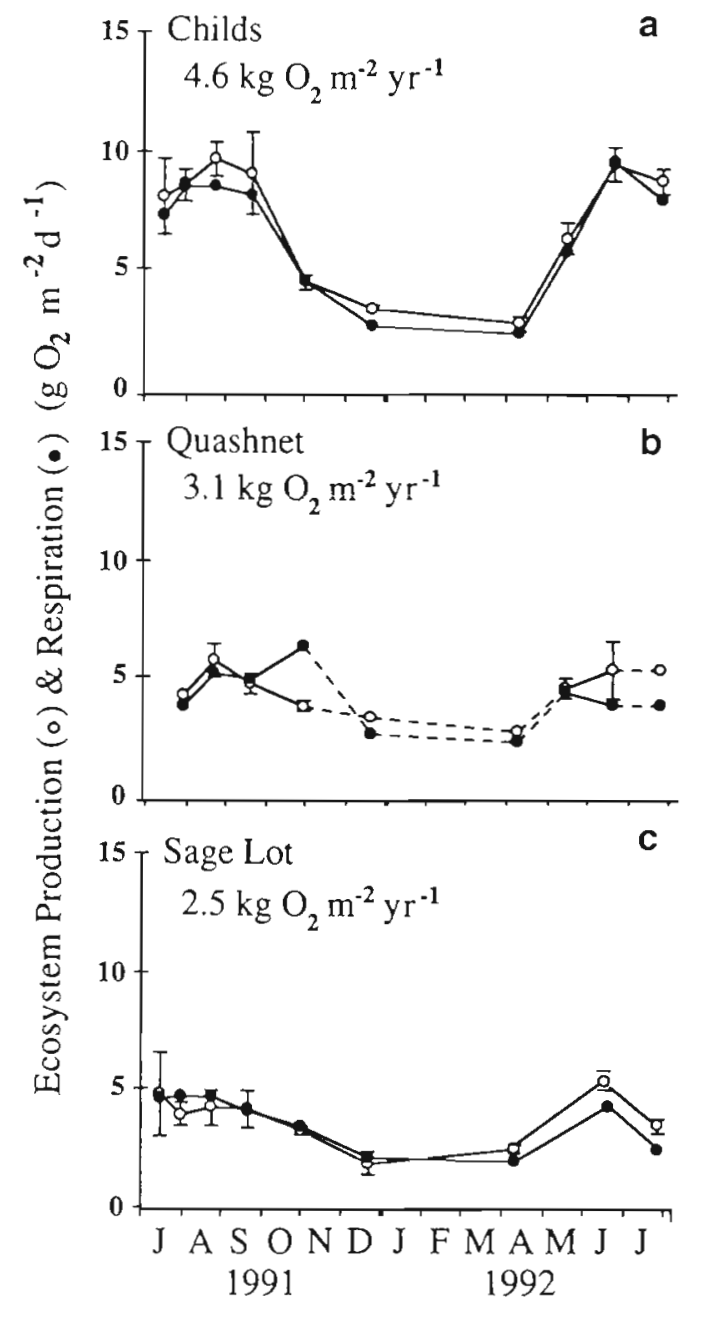

Fig. 6. Ecosystem production and respiration in the 3 estuarles over a year. Each point is the mean \pm SE of 5 to 25 consecutive days of each deployment of the $\mathrm{O}_{2}$ sensors. Annual integrals of gross production are indicated. Dotted line in the Quashnet River panel indicates missing data; Childs River data were used to estimate an annual integral

The rates of production in Childs River are comparable to other shallow temperate estuaries (Kemp \& Boynton 1980, Kenney et al. 1988). Nighttime ecosystem respiration during warmer months ranged from 5 to $10 \mathrm{~g} \mathrm{O}_{2} \mathrm{~m}^{-2} \mathrm{~d}^{-1}$ which is also comparable to community metabolism rates in other shallow estuaries (e.g. Kemp \& Boynton 1980).

\section{Annual totals}

Annual ecosystem net and gross production (ENP and EGP) were positively related to nutrient loading in Waquoit Bay (Fig. 7, open symbols). The difference in metabolism among the 3 estuaries was especially evi- dent during the warmer months (Figs 4 \& 5). Thus $N$ enrichment appears to stimulate the metabolism of both production and respiration and their net difference, particularly during summer, over the loading range estimated for these 3 estuaries.

The Childs River is autotrophic on an annual basis. Even though confidence limits for production and respiration of the deployments overlap, daytime $\mathrm{P}$ was consistently higher than nighttime $\mathrm{R}$ (paired $t$-test, $\mathrm{p}=$ $0.004)$ for all deployments. We estimated ecosystem net production (the excess of $\mathrm{P}$ over $\mathrm{R}$ integrated over the year) for this estuary of about $180 \mathrm{~g} \mathrm{O}_{2} \mathrm{~m}^{-2} \mathrm{YI}^{-1}$

For the Quashnet and Sage Lot estuaries, we calculated smaller annual ENP values of 67 and $42 \mathrm{~g} \mathrm{O}_{2} \mathrm{~m}^{-2}$ $\mathrm{yr}^{-1}$. However, the paired $\mathrm{P}$ and $\mathrm{R}$ comparison was not statistically significant $(p=0.97$ and 0.40 ). Further, the ENP for Sage Lot was positive only because daytime production was high (about $5.5 \mathrm{~g} \mathrm{O}_{2} \mathrm{~m}^{-2} \mathrm{~d}^{-1}$ ) and greater than nighttime respiration in June 1992 (Fig. 6). For the other warmer months, production averaged 4 or $5 \mathrm{~g} \mathrm{O}_{2} \mathrm{~m}^{-2} \mathrm{~d}^{-1}$ and was equal to respiration. Our rates are similar to eelgrass production rates measured by Conover (1968) in an estuary near Waquoit Bay. In addition, Short's (1980) model for annual pro-
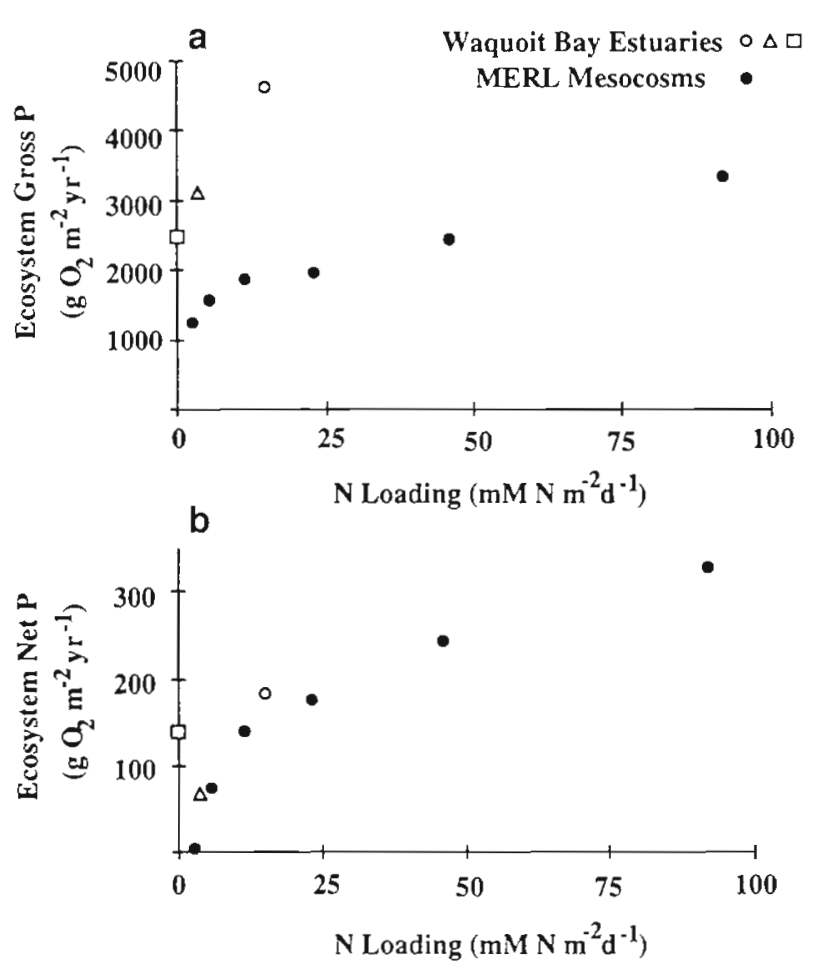

Fig. 7 Companson of annual ecosystem production as a function of $\mathrm{N}$ loading in 3 Waquoit Bay estuaries and the MERL mesocosms (Oviatt et al. 1986). (O) Childs River; ( $\triangle$ ) Quashnet; (a) Sage Lot Pond. (a) Ecosystem gross production versus the total $\mathrm{N}$ load per $\mathrm{m}^{2}$ of each estuary or mesocosm $\left(\mathrm{N}_{\text {nput }}\right)_{i}$ (b) ecosystem net production versus $\mathrm{N}_{\text {mpur }}$ 
duction of Zostera marina in a location similar to Sage Lot Pond predicts a summer peak in net production, although it occurs later than the one we observed.

\section{DISCUSSION}

\section{Measuring system metabolism from diel changes in free-water oxygen in open estuaries}

The assumption that diel changes represent metabolism within the subestuary is critical to our findings. Our analysis of variation within the estuary demonstrated that rates of $\mathrm{O}_{2}$ change were similar at the single station compared to at multiple sites along the estuary. It is clear that the measured changes are representative of the whole estuary. Further, this spatial variation was generally less than day-to-day changes in the site.

To assess the validity of a single station measurement, it is also useful to estimate the movement of the water over the diel period. For example, based on the tidal range $(0.5 \mathrm{~m})$, mean depth $(1.1 \mathrm{~m})$, and length of the river basin $(1.4 \mathrm{~km})$, we roughly estimate the tidal excursion for the Childs River as:

$$
E=(\text { tidal } \mathrm{range} / \mathrm{mean} \text { depth }) \times \text { length }=600 \mathrm{~m}
$$

Although this average excursion ignores bidirectional flow expected with strong stratification, it indicates that tidal advection is likely to be confined within the estuary during the intervals over which $\mathrm{P}$ and $\mathrm{R}$ are measured.

We conclude that application of the diel method for system metabolism measurement is valid in these embayments. This finding is perhaps not surprising because in Waquoit Bay water flows into the subestuaries from adjacent environments with similar substrate and biological structure. We argue that in some estuaries it is reasonable to relax the restriction of measuring ecosystem metabolism only in a closed system if the tidal excursion is less than the length of the estuary and thus if the water moving within the basin stays there for the length of the diel period. Further, if the adjacent habitats are essentially similar to the study area, similar metabolic rates are likely and water crossing the boundaries may have similar metabolic history. While advection and spatial heterogeneity certainly affect these data las is the case even in lakes or closed embayments where the method is deemed acceptable), we believe that our $P$ and $R$ measurements are an acceptable estimate of local metabolism. In the Waquoit Bay estuaries, it appears that the biological signal is strong in relation to changes in $\mathrm{O}_{2}$ due to physics (a high signal/noise ratio). Kemp \& Boynton (1980) have also shown that in shallow, productive estuaries physical factors may be less problematic in diel $\mathrm{O}_{2}$ budgets if biological factors dominate over appropriate sampling scales.

Correctly adjusting apparent surface $\mathrm{O}_{2}$ concentration for atmospheric exchange is another important consideration, especially in productive estuaries such as Waquoit Bay where daily flux rates during summer are as high as $40 \%$ of metabolic rates (D'Avanzo et al. unpubl.). We calculated net flux due to gas exchange across the air-sea interface from wind speed because our direct determinations of the gas exchange coefficient indicated strong correlations with wind speed measured simultaneously at each site (Kremer et al. unpubl.). In contrast, no relationship was found between gas exchange and surface current velocity, perhaps because bottom-induced turbulence, which influences gas exchange in some rivers, is effectively isolated from the surface by the strong density stratification in our estuaries. Further, if published generic equations were used rather than the site-specific regressions, substantial differences in calculated diffusive flux would occur, leading to implausible results (D'Avanzo et al. unpubl.).

\section{Phytoplankton and benthic macrophytes}

Comparison of annual phytoplankton production determined with light and dark bottles incubated in situ throughout the year (K. Foreman, Marine Biological Laboratory, Woods Hole, pers. comm.) with our total metabolism rates demonstrates that macrophytes are the dominant producers in all 3 estuaries. In the highly enriched Childs River, phytoplankton account for the greatest proportion of ecosystem production [gross plankton production (GGP) is $24 \%$ of ecosystem gross production]. In the other 2 estuaries, GPP is about $12 \%$ of EGP.

\section{Trophic state of coastal systems}

Our data provide information on 2 issues of general interest: the trophic state of shallow estuaries and the nature of these systems' response to eutrophication. It has been suggested that most shallow systems are heterotrophic on a net annual basis, although coastal systems undergoing cultural eutrophication may well be net autotrophic (Smith \& Mackenzie 1987, Smith et al. 1991). Carmouze et al. (1991) asserted that it is difficult to discern a common pattern of autotrophy versus heterotrophy in shallow, coastal systems because plant communities are diverse, community metabolism studies in these areas are few, and methods used are so varied.

Ecosystem net production (ENP) is a measure of fixed carbon not respired or consumed by herbivores 
within each estuary. Thus, net production measured over a year indicates an export or burial of organic matter from enriched estuaries. The Childs River is autotrophic most months and on an annual basis. Surveys of macroalgal biomass show no evidence of increased stocks over 4 yr (Hersh 1993) and burial is probably small (Berner \& Raiswell 1983). Thus we interpret our results as indicating export of organic matter from the highly enriched Childs River estuary. To put these rates in perspective, the annual ENP in Childs River (about $70 \mathrm{~g} \mathrm{C} \mathrm{m}^{-2} \mathrm{yr}^{-1}$ ) is about a quarter of the average macroalgal biomass in this location (Table 1). We also calculate positive annual ENP values for the other 2 estuaries, although the significance of these rates is uncertain because $P$ appears not to be consister.tly higher than R in these systems at any time of the year.

Several other studies have demonstrated positive annual ENP values in estuaries receiving $\mathrm{N}$ lodding. For example, Oviatt et al. (1986) found that ENP increased along the gradient of $\mathrm{N}$ loading in the eutrophication experiment in the MERL mesocosms. Nowicki \& Oviatt (1990) concluded that much of the nutrients added to these experimental systems were exported in dissolved or particulate organic forms. Annual ENP for the nutrient enriched Chesapeake Bay is positive in the mainstem lower bay (about $100 \mathrm{~g} \mathrm{C} \mathrm{m}^{-2} \mathrm{yr}^{-1}$ i Kemp et al. 1993) and about zero in the midbay. Finally, Reyes \& Merino (1991) measured positive net system $\mathrm{O}_{2}$ flux in a tropical lagoon receiving anthropogenic nutrient inputs.

\section{Ecosystem response to eutrophication}

Are the differences in system production in the Waquoit Bay estuaries a response to nitrogen loading? To address this we compared our values to other systems where $\mathrm{N}$ input has been estimated using Nixon's (1992) relationship between productivity and $N$ loading for various marine systems. On his $\log -\log$ axes, the Waquoit Bay estuaries appear consistent with the range of points from other systems.

We also compared our system production values in detail with those measured in the MERL eutrophication experiment because this is the only other study in which estuarine system metabolism was determined across a nutrient gradient. (Our loading rates fall in the range of the 1 to $8 \times$ MERL enrichments.) For the Waquoit Bay estuaries, both EGP and ENP increase with $\mathrm{N}$ loading (Fig. $7 \mathrm{a}$, b). The loading/metabolism relationship is fairly linear for the Waquoit Bay estuaries and hyperbolic for the MERL mesocosms, especially at the higher enrichments, but in both the response of system metabolism to loading is clearly positive.
However, Waquoit Bay EGP values are higher than the MERL rates at comparable loading inputs (Fig. 7a). This is a surprising finding because the residence time in MERL is much longer than in Waquoit (26 as opposed to $0.5-2 \mathrm{~d}$ ) and we anticipated that more recycling and hence higher EGP would occur in estuaries with longer residence times. This difference in metabolism in the 2 systems may be related to differences in $\mathrm{C}: \mathrm{N}$ of the most abundant producer types. The dominance of phytoplankton in MERL ( $\mathrm{C}: \mathrm{N}=6.6)$ versus macrophytes in Waquoit Bay ( $\mathrm{C}: \mathrm{N}=12$ to 18) could account for differences of 2 or 3 fold in carbon metabolism. Similarly, the $\mathrm{O}_{2}$ and $\mathrm{C}$ productivity achieved in Sage Lot given low levels of $N$ input must depend on the high $\mathrm{C}: \mathrm{N}$ of seagrass which are the dominant producers.

We also anticipated that ENP values in MERL would be lower than those in Waquoit Bay. Again, in the mesocasms with long residence times there is greater opportunity for consumption and regeneration, the ratio $P: R$ is near 1 , and $\Xi N P$ would be expected to be small. In contrast, in the more rapidly flushed Waquoit Bay we anticipated that some phytoplankton production would be exported, resulting in net system metabolism. Following this logic, net primary production should be different in estuaries experiencing large differences in water turnover time. Yet ENP in MERL and Waquoit Bay are fairly similar (Fig. 7b). This surprising finding suggests that similar rates of $\mathrm{N}$ utilization are possible even with quite high turnover times.

\section{Residence time}

Estuarine ecologists have recently included the concept of residence time in attempts to find a more meaningful and predictive relationship relating production and loading than Nixon's (1992) log-log relation. For lakes, Vollenweider (1976) improved the correlation between chlorophyll stock and phosphorus input by normalizing the loading with a term including the freshwater fill-time, and analogous factors have been suggested for estuaries (W. Boynton. Chesapeake Biological Laboratory, pers. comm., J. Garber, Narragansett Bay EPA, pers. comm.). However, for both the Waquoit Bay estuaries and the MERL mesocosms a pattern between system metabolism and enrichment occurs in direct response to $\mathrm{N}$ loading and no adjustment for residence time is necessary.

\section{Possible fates of the loaded $\mathrm{N}$}

$\mathrm{N}$ enriching coastal waters from contributing watersheds can be lost from an estuary through several processes. In Waquoit Bay nitrate in groundwater could 
be: (1) exported as unassimilated nitrate, (2) assimilated by producers and buried or exported as dissolved or particulate organic matter, (3) assimilated but remineralized in the benthos and exported as ammonium. and/or (4) denitrified. The relative importance of denitrification in relation to the other exports will determine the link between an estuary and connected ecosystems - whether loaded $\mathrm{N}$ is exported as organic or inorganic $N$ from the estuary.

We estimated the following budget for these processes in the Childs River: a loading rate of $5.4 \mathrm{~mol}$ $\mathrm{N} \mathrm{m}^{-2} \mathrm{yr}^{-1}$ and a denitrification rate of about 3 or $3.5 \mathrm{~mol} \mathrm{~N} \mathrm{~m}{ }^{-2} \mathrm{yr}^{-1}$ (M. LaMontagne, Boston University Marine Program, pers. comm.). ENP for Childs River is $180 \mathrm{~g} \mathrm{O}_{2} \mathrm{~m}^{-2} \mathrm{yr}^{-1}$. The $\mathrm{N}$ requirements for this exported production are about 0.5 to $0.9 \mathrm{~mol} \mathrm{~N} \mathrm{~m}^{-2} \mathrm{yr}^{-1}$ if the export is phytoplankton (assuming $\mathrm{C}: \mathrm{N}=6.6$ ) or seaweed $(C: N=12)$. Thus in this estuary about 50 to $60 \%$ of the loaded $\mathrm{N}$ appears to be lost as $\mathrm{N}_{2}, 10$ to $15 \%$ is exported or buried as organic matter, and any remainder may be exported as remineralized ammonium or unassimilated nitrate. Our estimate of the $\%$ of loaded $\mathrm{N}$ removed by denitrification is similar to that determined by Seitzinger (1988) for estuaries.

\section{Daily variability and replication in measuring ecosystem metabolism}

Our data demonstrate large day-to-day variability in ecosystem metabolism in these shallow, hydrologically dynamic estuaries. The advent of sensors capable of satisfactorily measuring dissolved oxygen throughout deployments of $2 \mathrm{wk}$ or longer allows the diel freewater $\mathrm{O}_{2}$ method to be used to measure ecosystem production and respiration with large day-to-day replication. Kenney et al. (1988) were the first to repeat measurements over many days. Logistical constraints limited their team's manual measurements to a single station, but annual patterns were convincing. The automated measurement of $\mathrm{O}_{2}$ allows conventional questions to be answered with added confidence, as well as permitting new questions to be addressed. In this study, we were able to document ecosystem-level response to day-to-day variations in light. We quantified variability in factors contributing to our estimates of ecosystem metabolism (instrument calibration, intraestuarine differences, diffusion) and concluded that the inter-estuarine differences reported here are believable. Between-estuary comparisons are far more compelling when based on consistent differences in paired comparisons of simultaneous measurements. Average rates may be determined over time intervals appropriate for meteorological or even tidal cycles. Seasonal patterns and among-site comparisons are statistically more robust when based on these representative averages. The ratio of daytime production to nighttime respiration can readily be distinguished from 1.0, and annual estimates of ecosystem net production have increased confidence. None of these comparisons would be statistically reliable with the limited replication of traditional manual diel $\mathrm{O}_{2}$ measurements. We feel that this approach could be applied successfully to many coastal systems.

Acknowledgements. The manuscript benefited greatly from the comments of Ivan Valıela, Ken Foreman, and an anonymous reviewer. Kerry Jo Guilfoyle, Michelle Hammes, and Robin McDonald conducted much of the field work and data reduction. We are grateful to Richard Payne from the Woods Hole Oceanographic Institute who provided irradiance data. Field work was conducted at the Waquoit Bay National Estuarine Research Reserve. The research was supported by subcontracts of the Waquoit Bay LMER project (NSF Grant \#OCE-8914729j to C.D'A and J.N., by NSF-REU grants to C.D'A., and by NSF grant OCE-9108413 to J.N.K.

\section{LITERATURE CITED}

Berner RA, Raiswell R (1983) Burial of organic carbon and pyrite sulfur in sediments over Phanerozoic time: a new theory. Geochim Cosmoschim Acta 47:855-862

Carmouze JP, Knoppers B, Vasconcelos P (1991) Metabolism of a subtropical Brazilian lagoon. Biogeochemistry 14: $129-148$

Conover JT (1968) Importance of natural diffusion gradients and transport of substances related to benthic marine plant metabolism. Botantica Mar 11:1-9

Costa JE (1988) Distribution production, and historical changes in abundance of eelgrass (Zostera marina) in south-eastern Massachusetts. PhD thesis, Boston University

D'Avanzo C, Kremer JN (1994) Diel oxygen dynamics and anoxic events in an eutrophic estuary of Waquoit Bay. Estuaries 18:131-139

Hartman B, Hammond DE (1985) Gas exchange in San Francisco Bay. Hydrobiologia 129:59-68

Hersh DH (1993) Effects of nutrient loading on abundance of macrophyte species in a shallow coastal bay. Abstracts, 12th Biennial Estuarine Research Federation Conf, Hilton Head, SC, Nov $14-18$, p 48

Jorgensen $B B$ (1977) The sulfur cycle of a coastal marine sediment. Limnol Oceanogr 21:814-832

Kemp WM, Boynton WR (1980) Influence of biological and physical processes on dissolved oxygen dynamics in an estuarine system: implications for measurement of community metabolism. Estuar Coast Mar Sci 11:407-431

Kemp WM. Smith E, Madden C, Cornwall J, Marvin M, Capone D. Boynton W (1993) Ecosystem metabolism and organic carbon balance in Chesapeake Bay. Abstracts, 12 th Biennial Estuarine Research Federation Conf, Hilton Head, SC, Nov Nov $14-18, \mathrm{p} 61$

Kenney BE, Litaker W, Duke CS, Ramus J (1988) Community oxygen metabolism in a shallow tidal estuary. Estuar Coast Shelf Sci 27:33-43

McComb AJ, Atkins RP, Birsh PB, Gordon DD, Lukatelich RJ (1981) Eutrophication in the Peel-Harvey estuarine system, Western Australia. In: Nielson BJ, Cronin LE (eds) Estuaries and nutrients. Humana Press, Clifton, NJ, p 83-110 
Nixon SW (1992) Quantifying the relationship between nitrogen input and the productivity of marine ecosystems. Pro Adv Mar Tech Conf 5:57-83

Nixon SW, Oviatt CA (1973) Ecology of a New England salt marsh. Ecol Monogr 43:463-498

Nixon SW, Oviatt CA, Frithsen J, Sullivan B (1986) Nutrients and the productivity of estuarine and coastal marine ecosystems. J Limnol Soc South Afr 12:43-71

Nowicki BL, Oviatt CA (1990) Are estuaries traps for anthropogenic nutrents? Evidence from estuarine mesocosms. Mar Ecol Prog Ser 66:131-146

Officer CB, Biggs RB, Taft JL, Cronin LE, Tyler MA, Boynton WR (1984) Chesapeake Bay anoxia: origin, development, and signuficance. Science 223:22-27

Oviatt CA, Keller A A, Sampou PA, Bcatty LL (1986) Patterns of productivity during eutrophication: a mesocosm experiment. Mar Ecol Prog Ser 28:69-80

Price KS, Flemer DA, Taft JL, Mackierman GB, Nehlsen W, Briggs RB, Burger NH, Baylock DA (1985) Nutrient enrichment of Chesapeake Bay and its impact on the habitat of striped bass: a speculative hypothesis. Trans Am Fish Soc $11.4: 97-106$

Reyes E, Merino M (1991) Diel dissolved oxygen dynamics and eutrophication in a shallow, well-mixed tropical lagoon (Cancun, Mexico). Estuaries 14:372-394

Seitzinger SP (1988) Denitrification in freshwater and coastal marine ecosystems: ecological and geochemical significance. Limnol Oceanogr 33:702-724

Short FT (1.980) A simulation model of the seagrass produc-

This article was presented by K. R. Tenore (Senior Editorial Advisor), Solomons, Maryland, USA tion system. In: Phillins RC, McRoy CP (eds) Handbook of seagrass biology: an ecosystem perspective. Garland Press, New York, p 277-295

Smith SV, Hollibaugh JT, Dollar SJ, Vink S (1991) Tomales Bay metabolism: C-N.P stoichiometry and ecosystem heterotrophy at the land-sea interface. Estuar Coast Shelf Sci 33:223-257

Smith SV, Mackenzie FT (1987) The ocean as a net heterotrophic system: implications from the global biogeochemical cycle. Global Biogeochern Cycles 1:187-198

Valiela I, Collins G, Kremer J, Lajtha K, Geist M, Seely B, Brawley J, Sham C (in press) Nitrogen loading from coastal watersheds to receiving waters: review of methods and calculation of loading to Waquoit Bay. Ecol Appl

Valiela I, Foreman $K$, LaMontagne M Hersh D, Costa J, Peckol P, DeMeo-Anderson B, D'Avanzo C, Babione M, Sham C. Brawley J, Lajtha K (1992) Couplings of watersheds and coastal waters: sources and consequences of nutrient enrichment in Waquoit Bay, Massachusetts. Estuaries 15:443-457

Van Raalte CD, Valiela I, Teal JM (1976) Productivity of benthic algae in artificially fertilized salt marsh plots. Limnol Oceanogr 21:862-872

Vollenweider RA (1976) Advances in defining critical loading levels for phosphorus in lake eutrophication. Mem Ist Ital Idrobiol 33:53-83

Wainrıght SC, Kremer JN, D'Avanzo C (1995) Evaluation of ENDECO $1184 \mathrm{C}$ dissolved oxygen recorders for use in temperate estuaries. Water Res 29:2035-2042

Manuscript first received: January 15, 1995

Revised version accepted: June 28, 1995 